\title{
Response to the commentary of Ide et al. "ghost/shadow cell differentiation in salivary gland tumors"
}

\author{
Stephan Ihrler ${ }^{1}$ (D) $\cdot$ Martin Mollenhauer ${ }^{2} \cdot$ Barbara Weitmayr $^{3} \cdot$ Christian J. Haas $^{1}$ \\ Received: 21 February 2020 / Revised: 21 February 2020 / Accepted: 21 February 2020 / Published online: 16 July 2020 \\ (C) Springer-Verlag GmbH Germany, part of Springer Nature 2020
}

\section{To the Editor,}

We read with interest the commentary of Ide et al. [1] on our brief report „Salivary ghost cell carcinoma: case report and proposal of a new entity "[2], which has recently been published in your journal. Obviously, we missed a 48-year old publication by Eversole et al. from 1972 [3] on 17 cases of mucoepidermoid carcinoma, shortly mentioning in the results a single case with putative focal ghost cell differentiation. This focal ghost cell differentiation had not been discussed in the abstract and in the discussion, rendering a discrepancy to Ide et al., claiming "a matter of particular interest to experts" [1]. In addition, this fact impeded a detection of this publication in our electronic search.

We are well aware of the fact, that the well-known ,pleomorphic "differentiation in pleomorphic adenoma of salivary glands may for some cases include a spectrum of cutaneous adnexal-type differentiation [4]. Concerning this matter in 2014 our group has contributed one of very few publications, comparing histopathology and molecular aspects of tumors of salivary glands and of cutaneous adnexal structures [5]. Due to limitations of words and references in brief reports in Virchows Archiv we had to abstain from a more detailed discussion on that important matter.

Apart from that, the two cases indicated by the authors of the letter to the editor may represent minor focal ghost cell differentiation in case of a mucoepidermoid carcinoma [3], and of pleomorphic adenoma [4], but they do certainly not represent a

Stephan Ihrler

Ihrler@dermpath-muenchen.de

1

2 Institute of Pathology, Technical University of Munich, Munich, Germany

3 Institute of Pathology and Microbiology, Krankenanstalt Rudolfstiftung, Wien, Austria salivary carcinoma with predominant ghost cell differentiation, as described in the brief report by our group [2].

\section{Compliance with ethical standards}

Conflict of interest The authors declare that they have no conflict of interest.

\section{References}

1. Ide F, Ito Y, Nishimura M, Kikuchi K, Kusama K (2020) Ghost/ shadow cell differentiation in salivary gland tumors. Virchows Arch

2. Ihrler S, Mollenhauer M, Weitmayr B, Haas CJ (2020) Salivary ghost cell carcinoma: case report and proposal of a new entity. Virchows Arch in press:1-4. https://doi.org/10.1007/s00428-01902657-y

3. Eversole LR, Rovin S, Sabes WR (1972) Mucoepidermoid carcinoma of minor salivary glands: report of 17 cases with follow-up. J Oral Surg 30:107-112. PMID: 4500489

4. Schmidt LA, Olsen SH, McHugh JB (2010) Cutaneous adnexal differentiation and stromal metaplasia in palate pleomorphic adenomas: a potential diagnostic pitfall that may be mistaken for malignancy. Am J Surg Pathol 34:1205-1210. https://doi.org/10.1097/PAS. 0b013e3181e658a5

5. Ihrler S, Weiler C, Eckert F, Mollenhauer M (2014) Cutaneous adnexal and salivary gland tumours. Similarities and differences Pathologe 35:476-486. https://doi.org/10.1007/s00292-014-1929-8

Publisher's note Springer Nature remains neutral with regard to jurisdictional claims in published maps and institutional affiliations. 